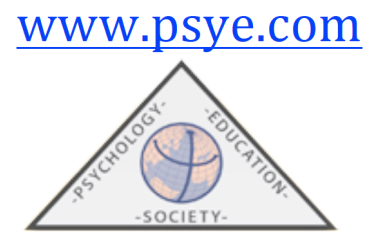

\title{
Teacher Professional Development in Finland: Towards a More Holistic Approach
}

\author{
Hannele NIEMI \\ University of Helsinki, Institute of Behavioral Sciences (Finland) \\ (Received on February 3, 2015; Accepted on June 29, 2015)
}

\begin{abstract}
The article reflects on teacher professional development as a continuum that starts during pre-service time, continues into the first years of newly qualified teachers' induction phase, and spans a career-long development throughout their teaching careers. Finnish teachers work in contexts that provide high professional autonomy and agency in their work. Pre-service teacher education prepares them for this responsible role. In earlier years, in-service training occurred on training days and through short courses. The new trend sees teachers as developers in the whole school community. Teachers have researchbased orientation in pre-service teacher education, which makes them capable to design school-based projects and their own development as it relates to school development. The article introduces four cases in which new trends have already been implemented. These best practices are examples how to (1) support the school community to cross boundaries towards multi-professional cooperation, (2) design an innovative school community using a design-based approach together with many partners, (3) connect pre-service and in-service research-based teacher education in science, technology and math (STEM) teaching, and (4) promote induction for new teachers.
\end{abstract}

Keywords: teacher education, induction, in-service, teaching profession

Correspondence: Hannele Niemi. Professor of Education. University of Helsinki, Institute of Behavioral Sciences. P.O. Box 9 (Street address: Siltavuorenpenger 5 A). FI-00014 University of Helsinki, Finland. Email: hannele.niemi@helsinki.fi

\section{How to cite this article?}

Niemi, H. (2015). Teacher professional development in Finland: Towards a more holistic approach. Psychology, Society and Education, 7(3), 278-294. 


\section{The European Policy for Teachers' Professional Development}

Teacher professional development (PD) can be defined in different ways. Many researchers regard PD as a series of processes that occur when teachers are working in schools after their graduation from teacher education institutes. This research is often focused on teachers' learning processes, school effectiveness and professional learning communities (e.g. Boyle, Lamprianou \& Boyle, 2005; Bruce, Esmonde, Ross, Dookie, \& Beatty, 2010; Hofman \& Dijkstra, 2010; Stoll, Bolam, McMahon, Wallace, \& Thomas, 2006). There is also another kind of an approach of teachers' professional development. According to many researchers (e.g. Conway, Murphy, Rath, \& Hall, 2009; Feiman-Nemser, 2001; Livingston, 2012; Livingston \& Shiach, 2010) professional development starts much earlier while teachers are still in preservice teacher education.

In the European Commission there is an emphasis that teachers' professional development should be supported through a 3-phase model: Initial teacher education, induction (for new teachers, 3-5 years after graduation), and in-service teacher education. This continuum supports teachers' career-long development. Based on the cooperation of many member countries, the European Commission (2010) published a handbook that recommends developing coherent and system-wide programs for teachers. It also includes recommendations for induction programs for beginning teachers:

This professional development of teachers is a lifelong process that starts at initial teacher education and ends at retirement. Generally this lifelong process is divided in specific stages. The first stage concerns the preparation of teachers during initial teacher education, where those who want to become a teacher master the basic knowledge and skills. The second stage is the first independent steps as teachers, the first years of confrontation with the reality to be a teacher in school. This phase is generally called the induction phase. The third phase is the phase of the continuing professional development of those teachers that have overcome the initial challenges of becoming a teacher (European Commission, 2010, p. 3).

European Union member states have agreed to work together to create the continuum of teacher education, ensuring that provision for teachers' initial education, early career support, and further professional development is coordinated, coherent, adequately resourced and quality assured. Another important aim is to encourage teachers to become reflective practitioners and autonomous learners in their own career-long professional development (Commission of the European Communities, 2007).

The continuum of teachers' professional career-long development has also been demanded by many researchers (e.g. Conway et al., 2009; Livingston, 2012). Livingston and Shiach (2009) emphasized the importance of a continuum of teacher training. According to Schwille and Dembélé (2007), we need a comprehensive framework for organizing and understanding how teachers acquire and improve their 
capacity to teach. In addition, these authors required the elaboration of policies and the design of teacher preparation and continuing professional development that optimally takes into account the whole spectrum of teacher learning, that is teachers' opportunities to learn from the beginning of their own schooling and throughout their teaching careers (Schwille \& Dembélé, 2007).

According to Feiman-Nemser (2001), teachers' own schooling has a powerful impact on their development as teachers, acting as a filter during their teacher education program and having an impact on what they learn. Livingston and Shiach (2010) emphasized that the first stage of the continuum of career-long professional development should enable student teachers to identify and explore their assumptions and personal experiences about learning and teaching through dialogue with peers and educators involved in their courses.

Livingston and Shiach (2010) emphasized that the development of an inquiry and reflective approach during initial teacher education should be part of a continuing process where teachers evaluated their own learning and planned their on-going professional learning needs throughout their careers. They recognized that in preservice time a questioning and critical inquiry approach is central to empowering teachers to take more responsibility for the progress of their professional learning and to reappraising their learning and teaching throughout their careers.

In Finland, teacher development is increasingly seen from the viewpoint of the teacher education continuum. Pre-service time lays the foundation on which inservice training can be built. In this article, teachers' development will be reflected from both a pre- and in-service viewpoint. Also induction, which has practically been nonexistent until recent years, will be an important theme. The article sets teachers' professional development into a Finnish teaching context and explains how preservice, induction, and in-service can promote teacher development.

\section{Pre-Service Teacher Education: Preparing for an Accountable and Autonomous Role}

In the Finnish system, teachers have much freedom, but they are also expected to take responsibility for different students' learning outcomes as well as students' holistic well-being. They have to recognize students' learning difficulties and identify special support needs as early as possible and in a timely manner. Teachers are expected to prepare students for lifelong learning. This requires a high degree of pedagogical competence and a wide professional role because students' learning is often connected to their attitudes, self-efficacy, and values. It also requires an ethical commitment to the profession. The Finnish education system is based on the following principles:

- Equity including lifelong learning as a value basis. Equity has been a leading principle of Finnish education policy since late 1960's. It covers the whole educational system from early education to higher education as well as adult education (Kumpulainen \& Lankinen, 2012; Niemi, 2014; OECD, 2006). The main objective of the Finnish education policy is to offer all citizens equal opportunities to receive education, regardless of age, domicile, financial 
situation, gender, or mother tongue. Education is considered to be one of the fundamental rights of all citizens.

- National curriculum system - local freedom and responsibility. The Finnish educational system is decentralized. Local education authorities are responsible for the provision and quality of educational service. Instead of a detailed, imposed national curriculum, there is a national curriculum system that provides values for the entire educational system and defines objectives for each educational level. Halinen and Holappa (2013) pointed out that local education authorities and schools are granted wide autonomy in organizing education and implementing the core curriculum. Teachers have extensive freedom regarding how they teach and what kinds of assessment methods they use. They can also select textbooks and other learning materials and can even choose whether to use textbooks at all. Local teachers, together with their principals, are responsible for the local school-based curriculum.

- Special need support. The basic education system is based on a strong inclusive ideology and support strategies for different learners. The main principle is that learners should be supported as early as possible in order to overcome learning difficulties. Teachers have to recognize needs for special support. If the standard aids given to all students is concluded to be insufficient based on multi-professionally conducted pedagogical assessment, intensified support is organized according to an individual learning plan (Vainikainen, 2014). Students are moved into special classes or schools only in extreme cases; commonly, they are provided with support within their own classes. Every teacher is responsible to identify a student's needs and make plans for that student's growth. This often happens in collaboration with special needs teachers, social workers, nurses, and school psychologists.

- National evaluation system - enhancement led evaluation. The Finnish educational policy has been an exception when compared with other high performing countries, especially Asian countries, as Finnish education does not include national standardized testing (Niemi, 2014). When teachers are not consumed with the pressure of standardized testing, they have the freedom to take care of student learning, and they can use various teaching and assessment methods depending on the students' needs. The purpose of assessments and evaluations is to improve learning and education. This principle is applied at both the macro and micro levels of the Finnish educational system.

Finnish pre-service teacher education has successfully generated high quality teachers for the educational system. Finland has been a top-performing country in many international comparisons (OECD, 2003; 2010; 2014). Teacher qualification law requires the Bologna process $2^{\text {nd }}$ cycle education from all teachers, which means that teachers must complete both a BA (180 ECTS, three years) and MA (120 ECTS, two years). Universities provide teacher education programs to different teacher categories, e.g., elementary teachers (grade levels 1-6), subject matter teachers for lower (grade levels 7-9) and upper secondary schools (grade levels 10-12), special 
needs teachers, study counselors for schools, and adult and vocational teachers. Student teachers can select study modules depending on their career path in the educational system. Study programs are not closed units, and students can design their own study plan according to the kind or kinds of formal qualifications (e.g., only elementary or secondary teachers' qualifications or both) they want to achieve. However, every teacher must fulfill basic criteria in the amount and quality of academic content knowledge and pedagogical studies with teaching practice.

The structure of teacher degrees at universities has been designed in such a way that teachers can easily widen or advance their formal qualifications after graduation by studying university modules for specific subjects, pedagogies, or multidisciplinary topics. Elementary teachers can extend their qualifications to secondary school teacher competence. Elementary and secondary school teachers can achieve special needs teacher competence by participating in one-year of additional university studies. Secondary school teachers sometimes want to study multidisciplinary modules and become elementary teachers for grades 1-6. All teachers also have a right to seek entrance to doctoral education. This is a typical learning path, especially for instructors in teacher training schools where student teachers have their teaching practice.

Teacher education, especially for elementary teachers, is among the most desired academic programs at universities. In the last 20 years, teacher education departments have received more applications per year than what is allowed by the teacher education quotas set by Ministry of Education and Culture. Selection is very competitive. Elementary teachers' programs accept $5 \%$ to $10 \%$ of all high quality applicants, and in subject teacher education programs, acceptance is $20 \%$ to $40 \%$ depending on the subject matter. In math, acceptance has been between $20 \%$ and $25 \%$ (FNBE, 2013).

Teacher education programs are academically demanding, but simultaneously, they lead to a professional practice. Theory and practice are integrated throughout studies. Teaching practice has three different phases: orientation, intermediate practicum, and advanced practicum, which expand student teachers' responsibilities (Jyrhämä, 2006). Experienced teachers at university teacher training schools and local partner schools supervise teaching practice. The aim is to encourage student teachers to be reflective and critical practitioners. In many surveys, student teachers have stated they value teaching practice very much and see it as the most important part of their professional development.

A special feature that differentiates the Finnish teacher education from many other countries is research studies in teacher education (Jyrhämä \& Maaranen, 2012; Niemi \& Jakku-Sihvonen, 2006). Every student teacher participates in research seminars or projects, learns different research methods that can be used in educational studies, and writes BA and MA theses. The aim is to learn about knowledge creation and scientific critical thinking. The leading principle has been that teachers need a thorough knowledge of the most recent research advances in the subjects they teach. In addition, they need to be familiar with the latest research on how something can be taught and learned. The aim is for teachers to internalize a 
research-oriented attitude toward their work. This means that teachers learn to take an analytical and open-minded approach to their work and that they develop teaching and learning environments in a systematic way. The most important abilities they learn through research studies are critical thinking, independent thinking, inquiring, scientific literacy, and questioning phenomena and knowledge (Niemi \& Nevgi, 2014). The general picture is very positive. Student teachers see research studies as valuable for the teaching profession and see their future work as a continuation of this developmental task. Jyrhämä and Maaranen (2012) have also analyzed teachers' and student teachers' concepts of and feedback on research studies in Finland. They found that through research studies, teachers learn alternative ways of working, reflecting, dialoguing, and gaining feedback for their work.

\section{Towards Long-Lasting Projects during In-Service Training}

In-service teacher education has many different forms in Finland. Officially there are three mandatory in-service training days for every teacher each year, but these can be used in very different ways depending on local decisions. However, in many schools teachers use much more time for their professional development. In Talis' review (OECD, 2013), Finnish teachers have less in-service training than teachers in other countries. This may be a real result, but it may also be a consequence of projects that are not purely traditional in-service training but more school-based development projects. In the Finnish educational system, local providers, the municipalities or cities are responsible for educational services. The local provider is also responsible for the quality of educational services at the local level, and school development and teachers' professional learning are often integrated.

Teachers' employers must provide resources for teachers' in-service training. Local providers can work together with state-funded projects of the Ministry of Education and Culture and the Finnish National Board of Education, both of which have funding calls for educational staff development. The municipality or city and its local schools can also have a contract with universities and their further education centers or private providers. They can also provide local and school-based training using teachers' expertise and peer-to-peer learning. The memorandum of the Advisory Board for Professional Development of Education Personnel (Hämäläinen, Hämäläinen, \& Kangasniemi, 2015) discussed the challenges and development needs for the professional development of education personnel in the coming years. The aim was to ensure that teachers are provided with systematic and sustainable support for their development.

The Finnish National Board of Education (FNBE) (Rajakaltio, 2014, p. 5) emphasized the following core values for the development of teaching profession competences:

- Life-long learning

- Knowledge and research-based orientation

- Effectiveness

- Anticipation of future needs and competences in education

The teaching profession is a learning profession, and teachers are expected to (C) Psy, Soc, \& Educ, 2015, Vol. 7(3) 
develop their work and profession throughout their careers. Finnish teacher education is based on a strong research orientation. This reflective and critical knowledge creation approach is also important for in-service training. In Finland, there is a strong movement from individual in-service training days towards more long-lasting development projects and programs that could be more sustainable in their effects. FNBE (Rajakaltio, 2014) outlined that staff training must integrate the latest research, knowledge from education evaluations, new knowledge creation, and competence development.

Most universities have education centers for teachers' in-service training. It is important that research-based and research-informed orientation of pre-service teacher education continues, and teachers can learn the most up-to-date and advanced knowledge of their subject matters as well as pedagogy through in-service training. The BA and MA programs have been planned to give teachers the theoretical and professional competences for managing their work in schools. University centers' inservice training provide more projects and longer development processes than short courses. The aim is that teachers critically reflect on their own work and create small design-based action research projects through which they learn new competences and also share new ideas with their colleagues. The goal is for in-service training to have a positive effect on students' learning and motivation, as well as teachers' own professional growth and well-being.

The Advisory Board for Professional Development of Education Personnel proposes that state-funded professional development should implement following principles:

- Collect and combine into a working entity the nationwide the orientation and mentor training supporting the initial phase of career and other necessary continuing education for new teachers in the process of transitioning from studies to work.

- Reinforce teachers' research-oriented work.

- In cooperation with their stakeholders, the higher education institutions will develop long-term programs to enhance the professional development of education personnel and new specialist trainings starting in 2015.

- Create a clear education path model enabling local variations from the fragmented offering of management trainings; the model will support the different career needs of managers and principals.

- Support the generation of peer-to-peer networks ensuring the professional competence required of the profession.

These aims outline state-funded in-service training that is only a complementary subvention to the local providers' organized in-service training. However, they reflect the trends that have been establishing more holistic programs and projects. The earlier day-based and short course-based trainings are no longer valid in school communities that must face very complex situations. Different teachers also have different needs, and that should be taken into account at local levels. 
The next sections describe four cases in which new trends have already been implemented. These best practices are examples of how to (1) support the school community to cross boundaries towards multi-professional cooperation, (2) design an innovative school community using a design-based approach together with many partners, (3) connect pre-service and in-service research-based teacher education in science, technology, and math (STEM) teaching, and (4) promote induction for new teachers.

\section{The School Community: Crossing Boundaries Toward Multi-Professional Cooperation}

The in-service project that aimed at sustainable and cooperative school development was carried out in cooperation with teacher education researchers at the University of Tampere, National Board of Education, and 15 local schools in 20102013. The project is an example how to integrate pre-service, in-service teacher education, and school communities. The project was based on the ideology that school development and teacher's professional development should go hand-in-hand. An important question was how to get schools to respond to changes and new requirements coming from a new law that organized special needs education in Finland. The project aimed at promoting an inclusive working culture as part of every-day life in schools. The project also wanted to strengthen multi-professional collaboration in schools. Special needs education required teachers' cooperation and collaboration with social workers, school psychologists, nurses, and other health-care professionals.

The core idea of the project was that schools, as multi-professional communities, provided a lot expertise that could be shared. The major problem was that schools often lacked forums where common thoughts, ideas, and competences could be shared (Rajakaltio, 2014). At the beginning of the study, teachers also expressed their concern that they have insufficient competence in facing students' needs and identifying their problems. They also felt pressure to meet the needs of different families and offer good learning opportunities to all children (Rajakaltio, 2014).

The project established an active dialogue with all partners in schools, local authorities, and the university researcher. The aim was that special education practices could be implemented in a very inclusive way. All multi-professional partners' ideas and initiatives were shared and discussed. The model was called a bipolar process: Bottom-Up and Top-Down. It was important that the new working models could be integrated with local municipalities' or cities' strategies for ensuring sustainability.

The project found several conditions that made school development successful. We may summarize them based on Rajakaltio's (2014) recommendations. Pedagogical leadership and principals' commitment in the project are keystones for successful development. Leadership can be shared, but the most important thing is that the whole school community sees the development as a joint task. In addition, development must be linked with a municipality's or city's strategic planning, and 
schools must have structures that support participation and an interactive dialogical culture in the whole school community. Teachers should also participate in joint development of their in-service training. Their needs should be taken seriously. Schools need multi-professional cooperation, learner-centeredness, networking inschool communities and with partners outside the school, and long-lasting development work.

This project connected individual teacher development and school development. As a result, the project revealed that it was important that teachers see their own development as part of school development and in-service training could be a resource for achieving joint aims in the school community. The schools' own teachers provided and shared new knowledge and practices with their colleagues. Sometimes experts from the outside were also needed. The most important thing was that schools had a communicative and cooperative working culture.

\section{Innovative School Community Using a Design-Based Approach}

The second case is an example how design-based research (DBR) and the development of school community were integrated when learning to use new communication and information technologies (ICT). The project was implemented in a school in the Helsinki Capital city area in 2012-2014 (Korhonen, Lavonen, Kukkonen, Sormunen, \& Kalle Juuti, 2014). Typical DBR projects are holistic and long in duration. The Innovative School Community (ISC) is a holistic model of a school environment that supports the learning and teaching of skills for the $21 \mathrm{st}$ century in local schools by applying new technology for cooperation. The project wanted to promote personalized learning with mobiles and home-school collaboration and connect students with surrounding neighborhoods, such as elderly homes, kindergartens, and libraries through new tools such as mobiles and iPads. Teachers worked as researchers and with researchers through several cycles, trying to create a new collaborative culture. DBR needs commitment from both teachers and researchers. The development processes consisted of four interdependent factors that were connected in all phases: Students' learning and learning environments, teachers' professionalism, leadership, and partnerships (Figure 1) (Korhonen et al., 2014). Teachers worked closely in teams and students were involved in all levels of new practices having several responsibilities in innovations.

In addition to internal collaboration, external partnership networks were important. It included parents, local community organizations and companies, as well as national and international networks. The ISC model emphasizes the role of all of these actors as innovators and encourages them to collaborate in the planning, implementation, and further development of the school's activities. These development activities are ongoing, iterative and cyclic, are based on assessment and are aligned with the latest technological and societal development (Korhonen et al., 2014).

The school's teachers wanted to develop their own work and were interested in learning new knowledge and skills. They were especially eager to learn about new innovations and technology and their potential uses in education (Korhonen et al., 
2014). They also recognized that staying on top of continuous change introduces new challenges and pressures.

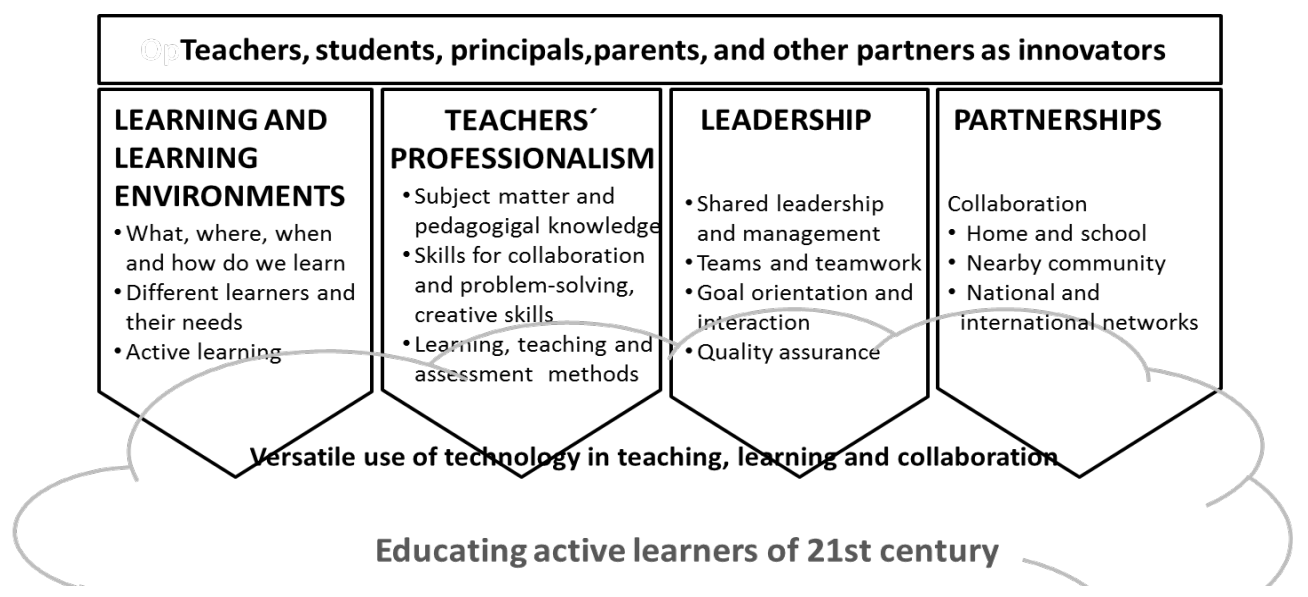

Figure 1. The Innovative School model (Korhonen et al., 2014)

According to teacher interviews (Korhonen et al. 2014), the teachers and researchers did share the same world through their engagement in DBR projects. However, this was not the case at the beginning of the project. Over time, the teachers learned to plan, implement, and evaluate DBR project activities. Especially, they adopted the iterative thinking of DBR.

\section{Connecting Pre-Service and In-Service Research-Based Teacher Education in Science, Technology, and Math}

In order to advance students' motivation to learn science and math and promote their learning outcomes, the LUMA Center was established at the University of Helsinki in 2003 (Vihma \& Aksela, 2014). It was named Finland's Science Education Center LUMA ( $\mathrm{L}$ and $\mathrm{U}$ are the first letters in science in Finnish, and $\mathrm{M}$ and $\mathrm{A}$ are the first letters in math) covering science, technology, and math (STEM) disciplines. For the first decade, the main goal of the LUMA center was to build a national ecosystem for collaboration on STEM education (Aksela, 2008). Since 2007, nine other regional LUMA Centers have been established within different Finnish universities. The current LUMA ecosystem is a social innovation in which universities, schools, teachers, students, guardians, and industry collaboratively engage children and young people from ages 3 to 19 in math, science, and technology and support research-oriented teachers at all levels for lifelong learning (Vihma \& Aksela, 2014). The core value of this collaboration is shared expertise. The LUMA Center Finland encourages all collaborating partners to share their ideas, experiences, and practices freely, in the spirit of open education. The center supports communality among children, youth, and teachers. Their natural interaction with the scientific community in the universities and industry is fostered, and their voice is a part of the design process of the LUMA activities (Vihma \& Aksela, 2014).

The LUMA Center supports teachers' lifelong learning through a continuum model (Aksela, 2008) that includes the following components: (1) pre-service training, (2) an induction stage, and (3) in-service training. The foundation for (C) Psy, Soc, \& Educ, 2015, Vol. 7(3) 
lifelong learning is created during the training of pre-service teachers. LUMA activities have been integrated into the training of both elementary and subject teachers at Finnish universities (Vihma \& Aksela, 2014). During their studies, preservice teachers are provided with authentic and regular experiences to interact with children and youth by leading different activities in the LUMA Center. Pre-service teachers also use the latest research information to actively produce teaching materials and ideas that benefit all teachers of STEM subjects in Finland.

The LUMA Center at the University of Helsinki supports formal STEM education at schools by providing teachers with opportunities to take their students to authentic STEM laboratories and classrooms located at nearby universities (Vihma \& Aksela, 2014). Pre-service students teachers take care of student learning in laboratories, and teachers can work with researchers in order to have the latest resources for their teaching. In addition, there are several other services through the LUMA centers, e.g., science clubs for children ages 3 to 6 years and teenagers, Webbased magazines for students and teachers, newsletters, and conferences.

Teachers' lifelong learning is supported by the pedagogical approach termed "learning by design," which places emphasis on learner-centered learning-by-doing in authentic contexts (Vihma \& Aksela, 2014). Teachers conduct a small educational design research project themselves (with the trainer's guidance). When this approach is applied to teacher in-service training, teachers are engaged in authentic design activities related to new educational learning environments and tools like ICT. Participating teachers collaborate closely to plan and execute their courses.

\section{Towards Induction}

TALIS 2013 (Teaching and Learning International Survey) is an international teaching and learning study carried out by the Organisation for Economic Cooperation and Development (OECD). The TALIS survey (OECD, 2013) revealed that teachers in Finland have fewer opportunities for developing in their profession, i.e., taking part in continuing education, than teachers in other countries who participated in the study. As mentioned earlier, the concept of continuing education focuses on transformation, and many school development projects are, in fact, also teacher professional development and in-service training. However, we can see that, for instance, formal induction is not very common in Finland as over $60 \%$ of primary schools do not provide any mentoring, which is deemed useful for new teachers. Mentoring is, in fact, not particularly widespread in any of the countries participating in the survey.

In order to find new solutions for supporting new teachers, there have been pilot projects that focused on mentoring new teachers in Finland. One project examined how to get the professional community to support all teachers' work and how to use group mentoring for facilitating new teachers' development (Jokinen, Morberg, Poom-Valickis, \& Rothma, 2008). The newest project aimed to create a program for supporting new teachers by using senior colleagues as personal mentors (Niemi \& Silajnder, 2013). 
In order to start the personal mentoring project, surveys were conducted among student teachers and new teachers (Niemi, 2011; Niemi \& Siljander, 2013). Based on the results, we can see that pre-service programs thoroughly provide professional skills that are fundamental in teaching, such as designing instruction and planning a teacher's work, using teaching methods, managing the classroom, and assessing different students. Student teachers also learn how to grow as professionals and what it means to be committed to the teaching profession. They also start to create their own educational philosophy and are ready for self-evaluation. Among the weakest competences, was collaboration inside and outside of the school community. A common feature of all these skills was the cooperation with partners outside a school community or tasks outside classrooms. The second weakest area was how they could help difficult students and support them in their learning. When the same questionnaire was presented to new teachers and they were asked what areas of the teaching profession they would need more support, the results totally corresponded with the pre-service study. The competences that were weak in pre-service time were at the top of their list. Newly qualified teachers did not need support in basic pedagogical and curricula issues, but they did need support for collaboration and especially for cooperation with parents.

The same result could be found in TALIS surveys. Teachers felt that teacher education failed to provide sufficient tools for matters such interacting with parents, collaborating with multiple professions, controlling disruptive behavior in the classroom, and catering to the needs of challenging students. They wanted to be able to learn how to apply ICT in teaching more $(16 \%)$, how to use new technologies in the workplace (14\%), and how to teach children with special needs $(10 \%)$.

In order to promote support during the induction phase, a group of researchers and experienced teachers published a handbook for mentoring in the Finnish context (Niemi \& Siljander, 2013). The first training cycle of mentors was organized according the handbooks' principles in 2013-2014. All mentors had newly qualified teachers as mentees whose professional development they supported. The course also provided additional support and updated knowledge about three special themes: a new special needs support system in Finnish schools, how to work with parents in conflict situations, and how to work in multicultural schools. Both mentors and mentees participated in these intensive trainings. The feedback from mentors and mentees was excellent. Both mentors and mentees expressed their delight that they had learned so much from each other. Both groups also had a unanimous message: induction and support for new teachers is really needed.

Even though we received very positive feedback from both mentors and mentees, in the future, training should be based on a more sustainable basis. Projects and pilots are important for opening new scenarios to mentoring and creating new knowledge for supporting new teachers. However, projects cannot solve the real problem in larger sense. Induction needs national and local structures. There is an urgent need to integrate the induction of new teachers within the structure of the education system. 
The project revealed that mentor training is a basic condition, but principals' support was also a key factor for induction. School leaders played an important role in organizing mentoring at a local level. Each new teacher should have an induction plan in which mentoring plays an essential role. Mentors could also be a huge resource for principals and school communities in the school's development.

Based on the experiences of the mentoring project we also learned that both mentors and mentees need an agreement that allows them to participate in an induction program and define how it is integrated with their work. Without time allocation and practical arrangement, induction is not sustainable. Teachers' and mentors' professional development need continuity, and this should be taken into account when organizing induction.

\section{Conclusions of the Finnish Teacher Professional Development}

Finnish teachers play a role that is often described as "teacher leadership". Lieberman (1992) and Hilti (2011) have outlined the knowledge base of this type of teacher. Teacher leadership means that teachers are goal-oriented and they should have a clear vision of school development and high-quality teaching, and moreover, they are able to work collaboratively and in interaction with other teachers towards those goals. Teachers should be able to consume research-based knowledge and have a thorough understanding of the teaching and learning process needed to act as a curriculum specialist. Professional development needs high quality pre-service education in which critical reflection and research orientation is important. But teachers' professional development also needs school-based structures that allow and encourage sharing and cooperation. School development cannot be separated from teachers' development.

In earlier years, Finnish in-service training was based on training days and short courses. These types of courses are still being offered to teachers, but the trend is towards a more holistic and integrated approach. The new trend is to see teachers as developers in the whole school community. Teachers have research-based orientation in pre-service teacher education, and this should be used as a resource. It makes teachers capable of designing school-based projects and also their own development as it relates to the school development.

Collaboration within the school community as well as with external partners, especially parents, is part of teachers' professional development, and they need support for that, especially in the beginning of their careers. Teacher work is becoming more and more complicated, and working in multi-professional cooperation is important, especially when students need special education.

The weakest link in the Finnish teacher education has been induction, which is practically missing. New teachers face so many complicated school conditions and demands in the Finnish educational system, that in spite of their high-quality preservice education, they need support when starting their teaching careers. One of the biggest reforms needed in the future involves providing all teachers with all this support. 


\section{References}

Aksela, M. (2008). The Finnish LUMA Centre: Supporting teachers and students in science, mathematics, and technology for life-long learning. Lifelong Learning in Europe, 13, $70-72$.

Boyle, B., Lamprianou, I., \& Boyle, T. (2005). A longitudinal study of teacher change: what makes professional development effective? Report of the second year of the study. School Effectiveness and School Improvements, 16, 1-27.

Bruce, C. D., Esmonde, I., Ross, J., Dookie, L. \& Beatty, R. (2010). The effects of sustained classroom-embedded teacher professional learning on teacher efficacy and related student achievement. Teaching and Teacher Education, 26(8), 1598-1608.

Commission of the European Communities (2007). Improving the quality of teacher education. Communication from the commission to the Council and the European Parliament 3.8.2007. Brussels.

Conway, P. F., Murphy, R., Rath, A. \& Hall, K. (2009). Learning to Teach and its Implications for the Continuum of Teacher Education: A Nine-Country CrossNational Study. Report Commissioned by the Teaching Council: Ireland.

European Commission (2010). Developing coherent and system-wide induction programmes for beginning teachers: a handbook for policymakers. Staff Working Document SEC (2010) 538 final, Directorate-General for Education and Culture. Brussels.

Feiman-Nemser, S. (2001). From preparation to practice: designing a continuum to strengthen and sustain teaching. Teachers College Record, 103(6), 1013-1055.

FNBE (Finnish National Board of Education) (2013). Teachers in Finland. http://www.oph.fi/download/156282_opettajat_suomessa_2013.pdf

Halinen, I., \& Holappa, M.-S. (2013). Curricular balance based on dialogue, cooperation and trust - The case of Finland. In W. Kuiper \& J. Berkvens (Eds.) Balancing Curriculum Regulation and Freedom across Europe. CIDREE Yearbook (pp. 39-62). Enschede: SLO Netherlands Institute for Curriculum Development.

Hilti, E. B. (Ed.) (2011). Teacher Leadership. The "New" Foundations of Teacher Education. A reader. New York: Peter Lang.

Hofman, R. H. \& Dijkstra, B. J. (2010).Effective teacher professionalization in networks? Teaching and Teacher Education, 26, 1031-1040.

Hämäläinen, K., Hämäläinen, K., \& Kangasniemi, J. (Eds.) (2015). Paths to Continuing Professional Development. The challenges and future of state-funded professional development of education personnel. The memorandum of the Advisory Board for Professional Development of Education [in Finnish; Abstract in English]. Publications of Ministry of Education and Culture 2015:10. Helsinki, Finland

Jokinen, H., Morberg, Å., Poom-Valickis, K., \& Rohtma, V. (2008). Mentoring newly qualified teachers in Estonia, Finland and Sweden. In Fransson,G. \& C. Gustafsson (Eds.), Newly qualified teachers in northern Europe. Comparative perspectives on promoting professional development (pp. 76-106). University of Gävle.

Jyrhämä, R. (2006). The function of practical studies in teacher education. In R. JakkuSihvonen \& H. Niemi (Eds.), Research-Based Teacher Education in Finland Reflections by Finnish Teacher Educators (pp. 51-70). Turku: Finnish Educational Research Association.

Jyrhämä, R., \& Maaranen, K. (2012). Research-orientation in a teacher's work. In H. Niemi, A. Toom, \& A. Kallioniemi (Eds.), Miracle of education: The principles and 
practices of teaching and learning in Finnish schools (pp. 97-110). Rotterdam, NL: Sense Publishers,

Korhonen, T., Lavonen, J., Kukkonen, M., Sormunen, K., \& Juuti, K. (2014). The Innovative School as an Environment for the Design of Educational Innovations. In H. Niemi, J. Multisilta, L. Lipponen, \& M. Vivitsou (Eds.), Finnish Innovations \& Technologies in Schools: Towards New Ecosystems of Learning (pp. 38-56). Rotterdam, NL: Sense Publishers.

Kumpulainen, K., \& Lankinen. T. (2012). Striving for educational equity and excellence: Evaluation and assessment in Finnish basic education. In H. Niemi, A. Toom, \& A. Kallioniemi (Eds.), Miracle of education: The principles and practices of teaching and learning in Finnish schools (pp. 69-81). Rotterdam: Sense Publishers.

Lieberman, A. (1992). Teacher leadership: What are we learning? In C. Livingston (Ed.), Teachers as leaders: Evolving roles (pp. 159-165). Washington, DC: National Education Association.

Livingston, K. (2012). Approaches to professional development of teachers in Scotland: pedagogical innovation or financial necessity? Educational Research, 54(2), 161172.

Livingston, K. \& Shiach, L. (2010). A new model of teacher education. In A. Campbell \& S. Groundwater-Smith, S. (Eds.), Connecting Inquiry and Professional Learning (pp. 35-45). Routledge: London.

Niemi, H. (2011). Educating student teachers to become high quality professionals - A Finnish case. Center for Educational Policy Studies Journal, 1(1), 43-66.

Niemi, H. (2014). Purposeful policy and practice for equity and quality - a Finnish case. In S. K. Lee, W. O. Lee., \& E. L. Low (Eds.), Education Policy Innovations: Levelling Up and Sustaining Educational Achievement (pp. 103-121). Singapore: Springer Singapore.

Niemi, H. \& Jakku-Sihvonen, R. (2006). Research-based teacher education. In R. Jakku Sihvonen, \& H. Niemi (Eds.), Research-based teacher education in Finland. Reflections by Finnish teacher educators (pp. 31- 50). Turku: Finnish Educational Research Association.

Niemi, H., \& Nevgi, A. (2014). Research studies and active learning promoting professional competences in Finnish teacher education, Teaching and Teacher Education, 43, 131-142.

Niemi, H. \& Siljander, A. M. and the group for developing mentoring (2013). New teachers Mentoring. Towards students' and teachers well-being through mentoring (in Finnish). Palmenia Centre for Continuing Education. University of Helsinki

OECD (2003). Organisation for Economic Co-operation and Development. First results from PISA 2003. Executive Summary. Retrieved Feb. 5, 2015 from http://www.oecd.org/education/preschoolandschool/programmeforinternationalstude ntassessmentpisa/34002454.pdf.

OECD (2006). Equity in Education. Thematic Review. Finland Country Note. Retrieved Feb. $\quad 5,2015$ from http://www.oecd.org/ document $/ 3 / 0,2340$,en_2649_34531_36296195_1_1_1_1,00.html.

OECD (2010). PISA 2009 Results: What students know and can do: Student performance in reading, mathematics and science (Volume I). Paris: OECD.

OECD (2014). PISA 2012 Results: (Volume V). Paris: OECD. Retrieved Feb. 5, 2015 from http://www.oecd.org/pisa/keyfindings/pisa-2012-results-volume-v.htm. 
OECD (2013), A Teachers' Guide to TALIS 2013: Teaching and Learning International. Survey, available at http://dx.doi.org/10.1787/9789264216075-en.

Rajakaltio, H. (2014). Towards renewing school. The action model of the school development - Integrating in-service-training and the development process. (In Finnish), Reports and 2014:9. Reports and reviews 2014:9. The Finnish National Board of Education, Helsinki, Finland.

Schwille, J., \& Dembélé, M. (2007). Global Perspectives on Teacher Learning: Improving Policy and Practice. International Institute for Educational Planning. UNESCO: Paris.

Stoll, L., Bolam, R., McMahon, A., Wallace, M. \& Thomas, S. (2006). Professional learning communities: A review of the literature. Journal of Educational Change, 7, 221-258.

Vainikainen. M-P. (2014). Finnish primary school pupils' performance in learning to learn assessments: A longitudinal perspective on educational equity. Faculty of Behavioural Sciences. Department of Teacher of Education Research Report 360. University of Helsinki.

Vihma, L. \& Aksela, M. (2014). Inspiration, Joy, and Support of STEM for Children, Youth and Teachers through the Innovative LUMA Collaboration. In H. Niemi, J. Multisilta, L. Lipponen, \& M. Vivitsou (Eds.), Finnish Innovations \& Technologies in Schools: Towards New Ecosystems of Learninng (pp. 72-84). Rotterdam, NL: Sense Publishers. 